\title{
Multifunctional Photo- and Redox-Active Tetrathiafulvalene-based Organogelators: A Modular Approach
}

\author{
David Canevet, Véronique Repussard, and Marc Sallé*[a] \\ Dedicated to the memory of Dr. Nuria Gallego-Planas
}

\begin{abstract}
A family of tetrathiafulvalene (TTF)-pyrene conjugates prone to gel various organic solvents was synthesized. Through a modular approach, the role of different chemical functions in the gelation process was assessed by varying systematically the alkyl chain length, the nature of the TTF-pyrene linkage, and the number of pyrene units. Moreover, one of these systems was thoroughly studied by NMR, UV/vis absorption, and fluorescence spectroscopy as well as by cyclic voltammetry, which showed their high potential in the context of molecular logics.
\end{abstract}

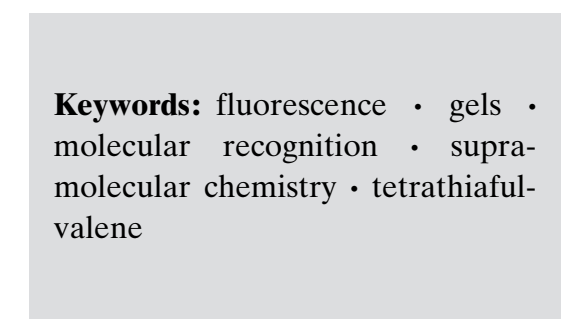

\section{Introduction}

The self-assembly of molecules into macroscopically organized architectures that are prone to immobilize organic solvents (organogelators) is well-established. ${ }^{[1]}$ Amongst the gelator family, low molecular weight organic gelators (LMWOGs) are particularly appealing. They offer a possible control over the macroscopic properties of the gel by chemical modifications of the gelator backbone at the molecular level. Of particular interest is the research towards stimuli-responsive gels, ${ }^{[2]}$ as these provide attractive and elegant access to stimuli-responsive soft materials for diverse applications ranging from bioscience to nanotechnology including sensing, ${ }^{[3]}$ molecular logic gates, ${ }^{[4]}$ and novel families of smart materials. ${ }^{[5]}$ On this ground, new gelation motifs are highly desirable for both fundamental and practical standpoints. Structural parameters which affect the gelation ability of organogelators are supported by a delicate balance between several simultaneous intermolecular noncovalent interactions. ${ }^{[6]}$ Nevertheless, the respective weight of these parameters are often challenging to anticipate, due to their crossed influence upon construction of the self-assembled nanostructure.

We recently described gelator $\mathbf{3 c}$ (Scheme 1 ) and its remarkable ability to gelate different solvents. ${ }^{[7]}$ This system, which was built according to a modular synthetic approach,

[a] Dr. D. Canevet, V. Repussard, Prof. Dr. M. Sallé Laboratoire MOLTECH-Anjou, CNRS UMR 6200 LUNAM Université, Université d'Angers 2 Bd Lavoisier, 49045 Angers Cedex (France) Fax: (+33) 241-735-405

E-mail:marc.salle@univ-angers.fr

Supporting information for this article is available on the WWW under http://dx.doi.org/10.1002/ajoc.201300261. associates several functional units within the same molecule, that is, a redox-active tetrathiafulvalene (TTF) moiety, ${ }^{[8]}$ two photoactive pyrene units, and amide linkers. ${ }^{[9]}$ Firstly, we evaluated the respective contributions of each fragment in the gelation process. This study was carried out on the basis of a modular approach where each part of the molecule was systematically addressed. In addition, the multifunctional structure of gelator 3c opens up very interesting perspectives regarding stimuli-responsive gels since bisamides constitute a well-established class of anion receptors ${ }^{[10]}$ and pyrene emission has been proven to be controlled in TTF-pyrene associations through redox processes. ${ }^{[11]}$ In addition to the study dealing with the gelating properties, we studied the ability of compound $\mathbf{3 c}$ to bind anions as well as the crossed effect of its redox and fluorescence properties.

\section{Results and Discussion}

\section{Synthesis}

The target systems $3 \mathbf{a}-\mathbf{c}$ were synthesized starting from the corresponding cyanoethyl-protected dithiolato-TTF derivative $\mathbf{1}$ (Scheme 1). Derivatives $\mathbf{1 a - c}$ were synthesized according to the literature. ${ }^{[7,12]}$ The corresponding dithiolate intermediates were generated upon treatment with cesium hydroxide and were treated with two equivalents of N-pyrenyl-2-chloroacetamide derivative $\mathbf{2}^{[13]}$ to afford the bispyrenyl-TTF conjugates $\mathbf{3 a - c}$ in reasonably good yields (56$75 \%$ after purification).

Several model compounds, varying by specific modifications on their constituent parts, were designed to address the capability of this class of TTF derivatives to generate organogels. On this ground, the monosubstituted TTF ana- 

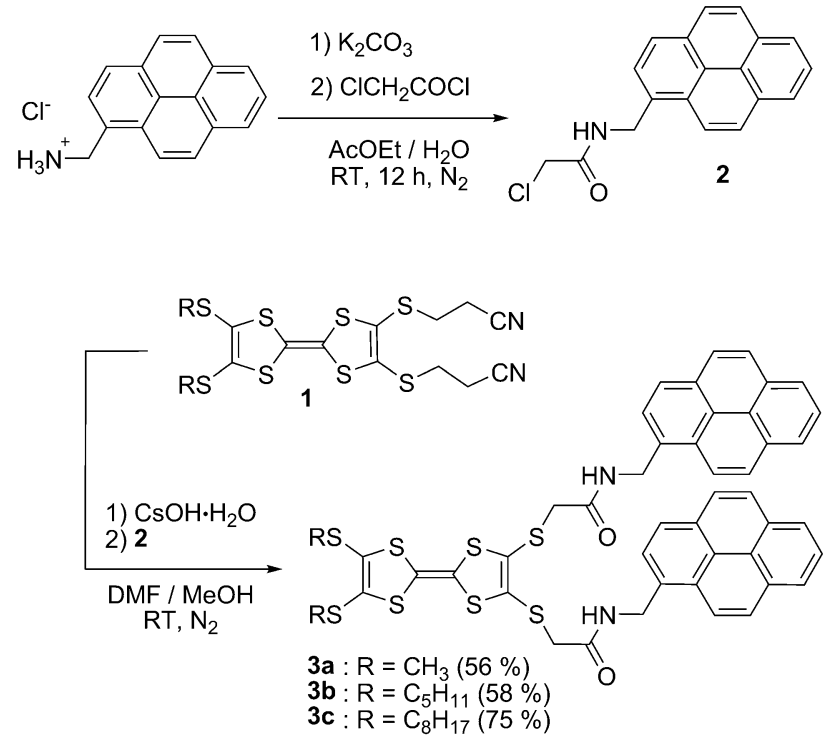

Scheme 1. Synthesis of compounds $3 \mathbf{a}-\mathbf{c} . \quad \mathrm{DMF}=N, N$-dimethylformamide.

logue 4c was prepared in two steps from compound $1 \mathbf{c}$ and according to a similar procedure as for $\mathbf{3 c}$ (Scheme 2).

On the other hand, the 1,3-dithiole rings 6 and 7 were synthesized from the tetraethylammonium bis(2-thioxo-1,3-
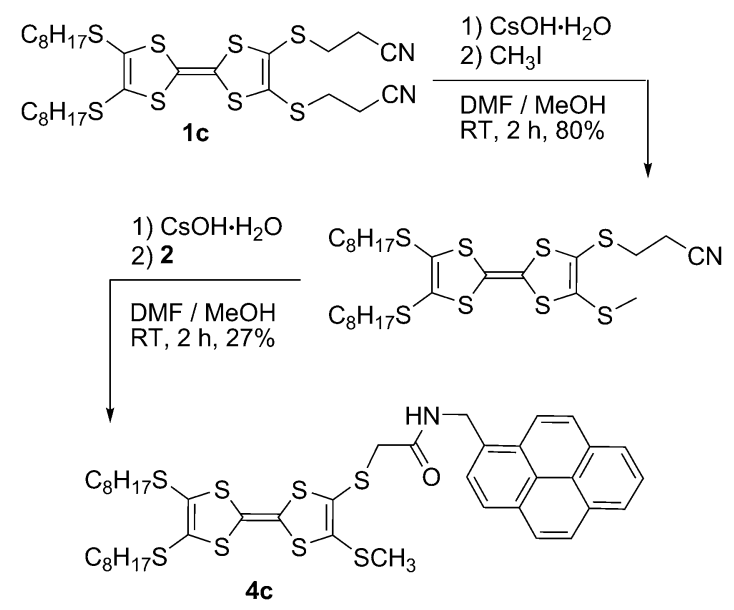

Scheme 2. Synthesis of compound $\mathbf{4 c}$.

Abstract in French: Différentes associations tétrathiafulvalène-pyrène susceptibles de former des gels dans des solvants organiques ont été synthétisées. En faisant varier systématiquement certains paramètres structuraux, le rôle des différentes sous-unités dans le processus de gélification a pu être établi. En outre, une de ces espèces a été étudiée en détail par spectroscopies RMN, d'absorption UV-visible et de fluorescence mais aussi par voltammétrie cyclique. Ces résultats montrent le fort potentiel des dérivés de type bisamide dans le domaine de la logique moléculaire.

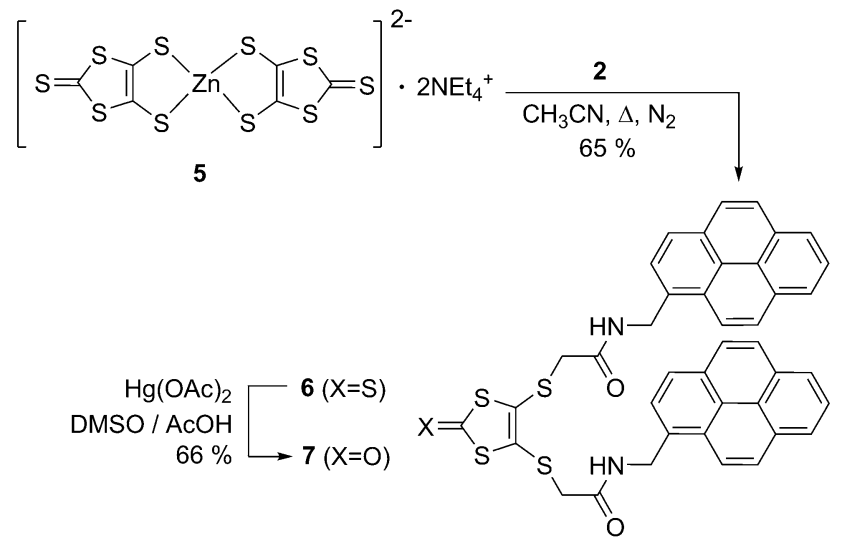

Scheme 3. Synthesis of compound 7. DMSO=dimethyl sulfoxide

dithiole-4,5-dithio)zincate salt $\mathbf{5}^{[14]}$ by reaction with four equivalents of acetamide $\mathbf{2}$, to reach thione $\mathbf{6}$, which was subsequently transchalcogenated to afford the oxygenated analogue 7 (Scheme 3).

In order to enlarge the study of the relationship between the molecular structure and the ability to generate gels, derivative $\mathbf{8}$, which does not contain any S-heterocycle, was designed. In this case, the nanostructuring occurring in the gel formation process, if any, could not result from the wellknown S $\cdots S$ interactions that are typical from ethylenedithio-TTF derivatives. ${ }^{[15]}$ The synthesis was carried out by reaction of chloroacetamide $\mathbf{2}$ with catechol under basic conditions and afforded compound $\mathbf{8}$ as a beige solid (Scheme 4).

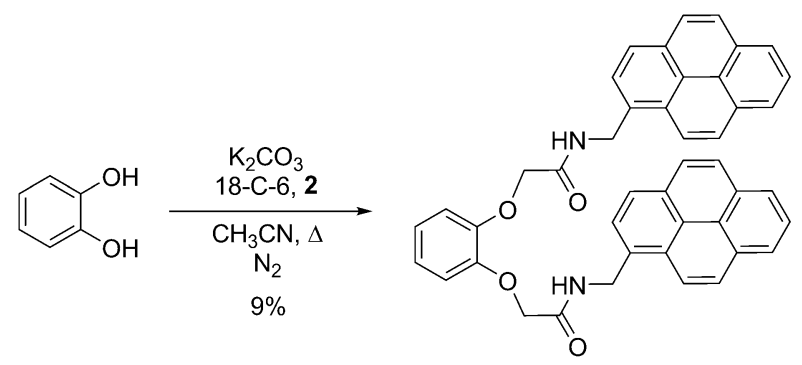

Scheme 4. Synthesis of compound 8. 18-C-6=18-crown-6.

Finally, still with the aim of contributing to the study of the structure/gelation relationships, several ester derivatives were also synthesized. According to similar synthetic approaches as those developed for their amide analogues $(\mathbf{3}$ and 6 respectively), the syntheses of diester derivatives $\mathbf{1 0 c}$ and $\mathbf{1 1}$ were attempted by a nucleophilic substitution from their dithiolato precursors (zinc salt $\mathbf{5}$ and 1c respectively) and pyrenyl 2-chloroacetate $\mathbf{9}^{[16]}$ the latter being obtained by esterification of 1-hydroxymethylpyrene with chloroacetyl chloride (Scheme 5). Whereas 1,3-dithiol-2-thione 11 was isolated in good yield following this strategy and was further converted into its oxo analogue 12, the reaction of 1c with 9 did not proceed. Instead, the preparation of the 

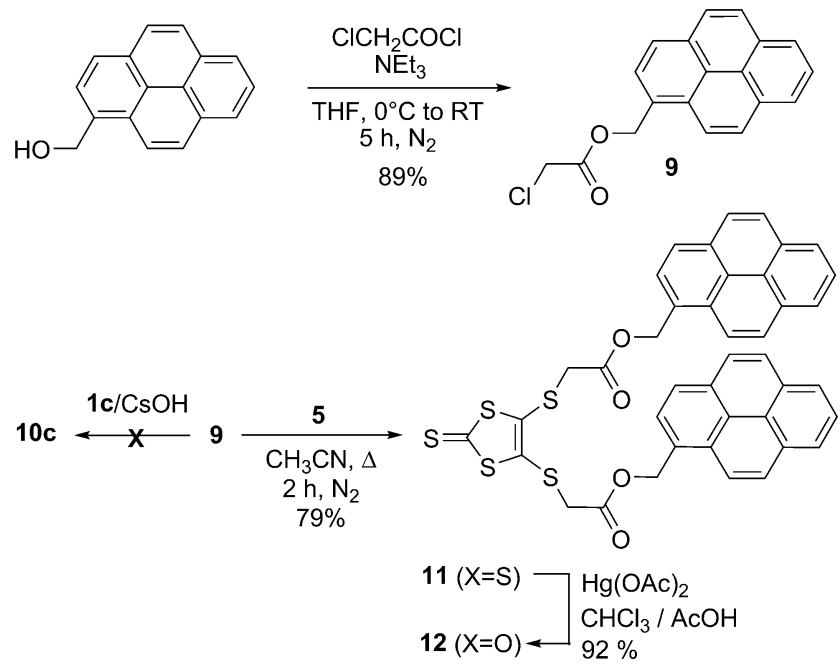

Scheme 5. Synthesis of compound $\mathbf{1 2}$.

diester 10c was accomplished by an alternative synthetic strategy, that is, by esterification of the diacid TTF $16 \mathbf{c}$. The latter was synthesized in five steps from zincate salt $\mathbf{5}$ (Scheme 6) through an adaptation of a reported procedure ${ }^{[17]}$ The final double esterification proceeded in reasonable yield to afford the target diester TTF derivative 10c (Scheme 7).

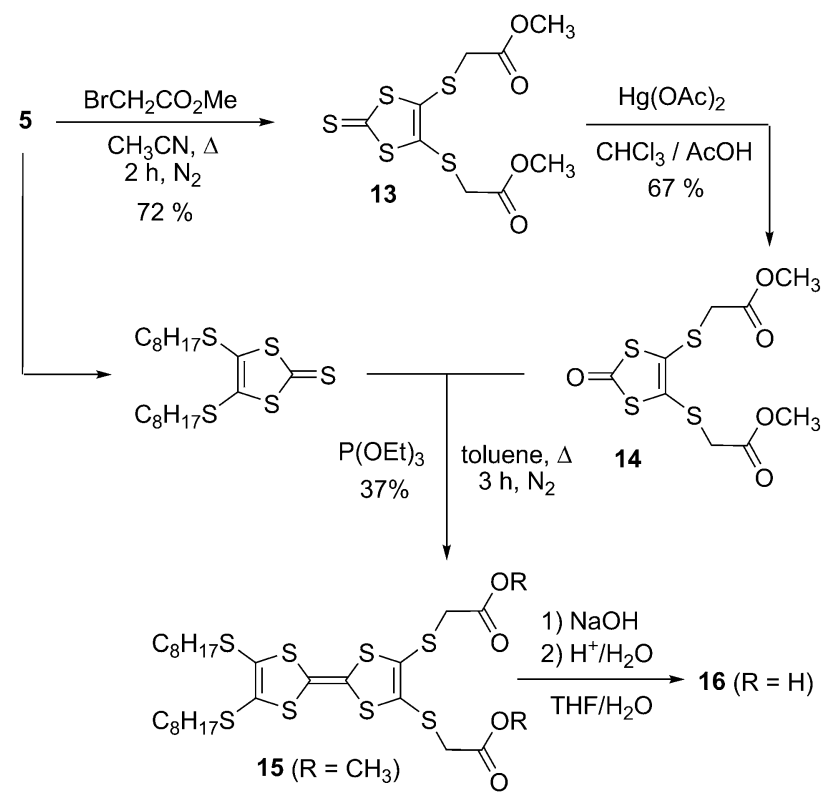

Scheme 6. Synthesis of diacid $\mathbf{1 6}$.

\section{Structural Parameters Governing Gelation from Organogelators 3}

We recently described the remarkable organogelating properties of compound $\mathbf{3 c} \mathbf{c}^{[7]}$ This compound is able to form varied self-assembled nanostructures that can be reached through choice of the solvent (chloroform, chlorobenzene,

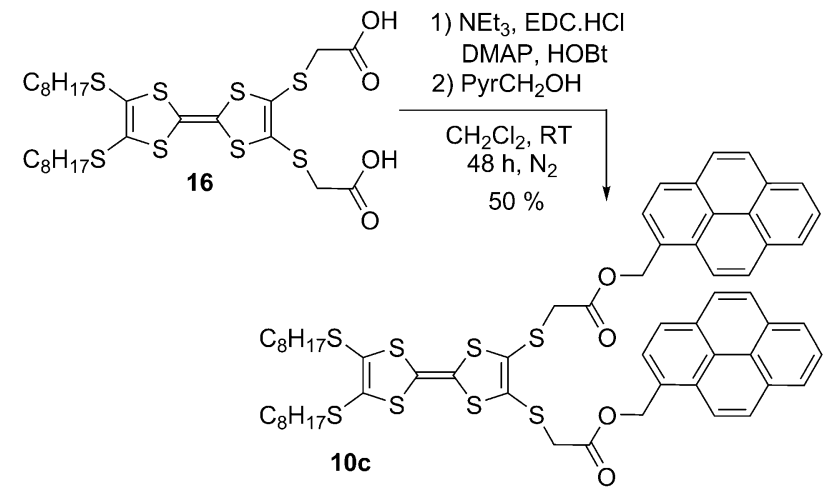

Scheme 7. Synthesis of diester 10c. DMAP $=4-N, N$-dimethylaminopyridine; $\mathrm{EDC}=1$-ethyl-3-(3-dimethylamino-propyl)carbodiimide; $\mathrm{HOBt}=$ 1-hydroxybenzotriazole.

1,2-dichlorobenzene, or even in tetrahydrofuran) and the medium (solution or gel) from which it is processed. It is able, for instance, to promote gel formation at a critical gelation concentration (CGC) value as low as $5 \mathrm{mg} \mathrm{mL}^{-1}$ $\left(4.5 \times 10^{-3} \mathrm{~mol} \mathrm{~L}^{-1}\right)$ in 1,2-dichlorobenzene. We ascribed this remarkable feature to the conjunction of several types of noncovalent interactions, that is, hydrogen-bonding promoted by two secondary amide groups as well as $\pi$-stacking arising from the two pyrene fragments. Moreover, a contribution of the TTF units can be speculated given the fact that doping of the gels with iodine results in conducting materials, in accordance with a stacked arrangement within the supramolecular organization.

On this ground and with the goal to optimize the structure/gelating property relationship of this class of multifunctional gelators, we have individually addressed each part of the molecule. Such a study will help in getting a better knowledge of the mutual influence of the different noncovalent interactions which occur within the corresponding supramolecular assemblies.

We first evaluated the impact of the amphiphilic character of such systems through the synthesis of compounds $\mathbf{3 a}$ and $\mathbf{3 b}$, which only differ from $\mathbf{3 c}$ by the nature of the $\mathrm{R}$ alkyl chain. Despite a shorter alkyl chain $(\mathrm{R}=n$-Pent $)$ than for $\mathbf{3 c}$, compound $\mathbf{3 b}$ also has a good ability to gel 1,2-dichlorobenzene $\quad\left(\mathrm{CGC}=8 \mathrm{mg} \mathrm{mL}^{-1}=7.9 \times 10^{-3} \mathrm{~mol} \mathrm{~L}^{-1}\right) . \quad$ A more striking result comes from the fact that compound $\mathbf{3 a}$ $(\mathrm{R}=\mathrm{Me})$ is also able to form gels with this solvent at a CGC value of $12 \mathrm{mg} \mathrm{mL}^{-1}\left(1.3 \times 10^{-2} \mathrm{~mol} \mathrm{~L}^{-1}\right)$. Therefore, though the gelation ability decreases as expected with the chain length - a three times higher molar concentration is required to get a gel from $\mathbf{3 a}$ than for $\mathbf{3} \mathbf{c}$-the fact that the former can generate a gel was totally unexpected. It is indeed well-established that long $\mathrm{R}$ alkyl chains are generally required to support a gelation process, by contribution of van der Waals interactions. To the best of our knowledge, no example of TTF-based organogelators bearing alkyl chains shorter than dodecyl groups is described in the literature.

Self-assembled nanostructures originate in general from a delicate balance between non-covalent interactions. 
Therefore, the gel formation from 3a can presumably be explained by occurrence of a favourable interplay of intermolecular interactions which compensate the low amphiphilic character of the compound. This is supported in the case of compounds of the $\mathbf{3 a}-\mathbf{c}$ family, by the multifunctional character of the gelators for which several coexisting noncovalent interactions are expected. At this stage, the key role of the secondary amide function in constructing the self-assembled nanostructure must be stressed.

The role of the amides can be illustrated through the gel formation studies of compounds $4 \mathbf{c}$ and $10 \mathbf{c}$, which both contain two octyl chains, as does organogelator $\mathbf{3 c}$. Compound 4c bears only one amide-pyrene pendant group. As anticipated from the impossibility to generate long-range intermolecular interactions from a single function, this compound does not form a gel in any of the organic solvents tested.

From this point of view, the behaviour of compound 10c is significant as it contains two pyrene pendant groups, which can potentially contribute to the self-assembly process through $\pi-\pi$ interaction. In order to control the specific effect promoted by the pyrenyl groups, this compound is devoid of hydrogen-bond-donating/accepting sites through replacement of secondary amide groups of $\mathbf{3} \mathbf{c}$ by ester functions. Compound $10 \mathrm{c}$ is obtained as a viscous yellow gum, which contrasts with the yellow solid obtained with the structural diamide analogue $\mathbf{3 c}$ and which provides a first qualitative indication that intermolecular $\pi-\pi$ interactions, if any, do not contribute significantly to the gel formation. This is confirmed by the absence of gel formation with $\mathbf{1 0} \mathbf{c}$ in 1,2-dichlorobenzene, even for concentrations as high as $50 \mathrm{mg} \mathrm{mL}^{-1}\left(2.3 \times 10^{-2} \mathrm{~mol} \mathrm{~L}^{-1}\right)$.

Finally, the contribution of the TTF backbone in the gelation process can be specifically addressed by comparing the gelating properties of compound $\mathbf{8}$, which only differs from organogelators $\mathbf{3 a}-\mathbf{c}$ by replacement of the TTF unit with a benzene ring. Interestingly, it appears that compound 8 is able to gel 1,2-dichlorobenzene with a CGC value of $12 \mathrm{mg} \mathrm{mL}^{-1}\left(1.8 \times 10^{-2} \mathrm{~mol} \mathrm{~L}^{-1}\right)$, which is significantly higher than for compound 3a. This difference may be ascribed to the smaller extension of the phenyl ring compared with the TTF scaffold and thus, to weaker intermolecular $\pi-\pi$ interactions.

Considered together, the results obtained from $4 \mathbf{c}, \mathbf{8}$, and $10 \mathrm{c}$ account for the critical role of secondary amide functions in promoting the gelation process.

\section{Electrochemical Behaviour of 3c}

The multifunctional character of $\mathbf{3 c}$ is, in particular, supported by the presence of a redox-active TTF unit within the structure, and its electrochemical behaviour was previously reported. ${ }^{[7]}$ As shown by cyclic voltammetry (CV), this compound undergoes two reversible oxidation processes at $\mathrm{E}_{1}{ }_{1}^{1} / 2=0.01 \mathrm{~V}$ vs $\mathrm{Fc} / \mathrm{Fc}^{+}$and $\mathrm{E}_{2}{ }^{1} / 2=0.40 \mathrm{~V}$, which are ascribed to successive monoelectronic oxidations of the TTF framework to cation-radical and dication states, re-

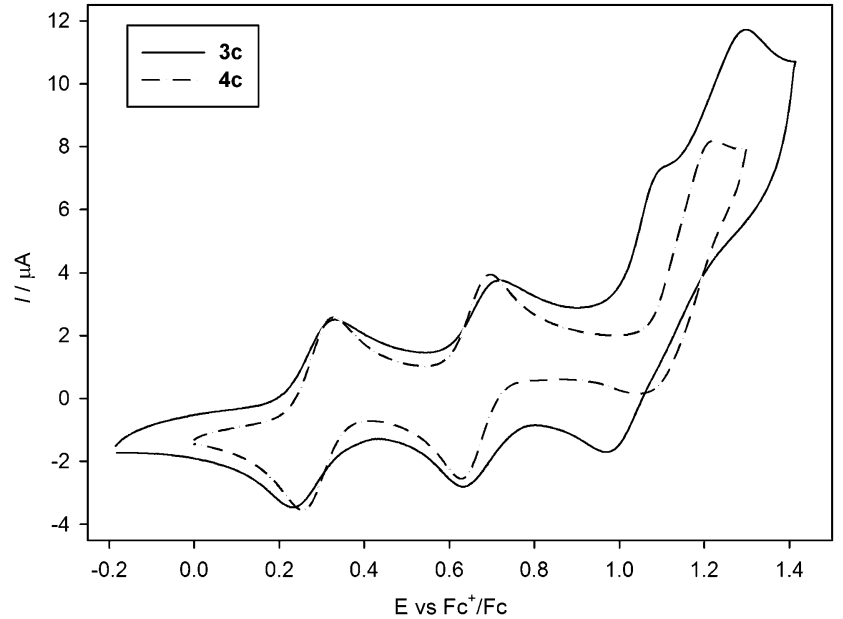

Figure 1. Cyclic voltammograms of compounds $3 \mathbf{c}$ and $4 \mathbf{c}\left(\mathrm{CH}_{2} \mathrm{Cl}_{2}, c=\right.$ $\left.5 \times 10^{-4} \mathrm{~mol} \mathrm{~L}^{-1}, \mathrm{Bu}_{4} \mathrm{NPF}_{6}\left(0.1 \mathrm{~mol} \mathrm{~L}^{-1}\right), \mathrm{V}=100 \mathrm{mV} \mathrm{s}^{-1}, \mathrm{Pt}\right)$.

spectively (Figure 1). Two additional redox processes are found at $\mathrm{E}_{3}{ }^{1} / 2=0.76 \mathrm{~V}$ and $\mathrm{E}_{4 \mathrm{p}}=1.04 \mathrm{~V}$ vs $\mathrm{Fc} / \mathrm{Fc}^{+}$. These processes are assigned to one-electron oxidations of both pyrene units to their radical-cation state. This two-step behaviour is attributable to the successive oxidation of the intramolecular mixed-valence (Pyr-Pyr) ${ }^{+}$dimer intermediate $^{[18]}\left(\mathrm{E}_{3}{ }^{1} / 2\right)$ and to the irreversible oxidation of the second pyrenyl unit $\left(\mathrm{E}_{4 \mathrm{p}}\right){ }^{[19]}$ This hypothesis is confirmed by the $\mathrm{CV}$ experiment on the monopyrenyl analogue $\mathbf{4 c}$ (Figure 1). In this case, the TTF unit is reversibly oxidized at similar potentials to $\mathbf{3 c}$, and these oxidations are followed by a third redox process corresponding to the oxidation of the pyrenyl fragment at $\mathrm{E}_{3 \mathrm{p}}^{\prime}=0.86 \mathrm{~V}$ vs $\mathrm{Fc} / \mathrm{Fc}^{+}$. It is noteworthy that the latter is situated in between both oxidation peaks of pyrenyl units of $\mathbf{3 c}$, in good agreement with the stabilization of the mixed-valence (Pyr-Pyr) ${ }^{+}$dimer at $\mathrm{E}_{3}{ }^{1} / 2$ and with the higher energy that is required to oxidize the remaining pyrenyl once the stable cation-radical pyrenyl dimer is formed in $\mathbf{3 c}$.

\section{Anion Recognition by Compound 3c}

Anions are known to be efficiently bound by secondary amide functions, and several examples of TTF receptors bearing amide groups have been reported. ${ }^{[17 b, 20]}$ The case of compound $\mathbf{3 c}$ is of particular interest as, in addition to the incorporation of TTF and amide units, it is built according a tweezers-like structure. The main interest in such molecular clips ${ }^{[21]}$ lies in their capability to conformationally alter their structure to increase the binding efficiency for a given guest. In the case of electron-rich tweezers such as $\mathbf{3 c}$, the amide function is prone to interact with an anion, and the electron-donating pyrene-based tips of the tweezers provide an additional potential intermolecular interaction that may be useful to bind a complementary guest.

Typically, the guest should be electron-deficient to interact with the TTF tips, and planar to fit within the host cavity defined by the two tips. On this basis, we preliminary 
explored the ability of $\mathbf{3 c}$ to bind different monoanions of various shapes (spherical, tetrahedral, linear, and trigonal) and this study was carried out by solution ${ }^{1} \mathrm{H} N M R$. Remarkably, among all the anions tested $\left(\mathrm{Cl}^{-}, \mathrm{ClO}_{4}^{-}, \mathrm{CN}^{-}\right.$, $\mathrm{CH}_{3} \mathrm{CO}_{2}^{-}, \mathrm{PhCO}_{2}^{-}$, and $\mathrm{H}_{2} \mathrm{PO}_{4}^{-}$), the most significant result concerns the benzoate anion. The evolution of the ${ }^{1} \mathrm{H}$ NMR spectrum of $\mathbf{3 c}$ in $\mathrm{CDCl}_{3}$, with the progressive addition of aliquots of $\mathrm{PhCO}_{2}^{-}$(introduced as the tetrabutylammonium salt) is presented in Figure 2. Two main issues can be pointed out from this titration experiment. A strong
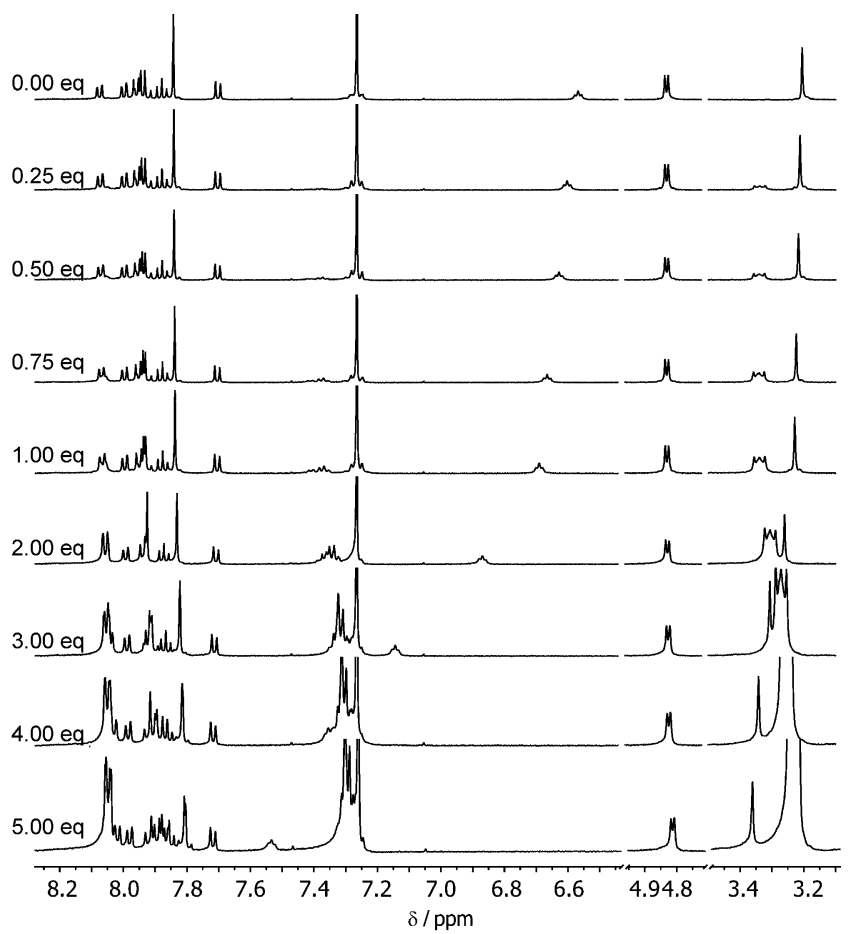

Figure 2. ${ }^{1} \mathrm{H}$ NMR titration of compound $\mathbf{3 c}$ with $n \mathrm{Bu}_{4} \mathrm{NPhCO}_{2}\left(\mathrm{CDCl}_{3}\right.$, $c=5.4 \mathrm{~mm})$.

deshielding of the $\mathrm{N}-\mathrm{H}$ signal from $\delta=6.56 \mathrm{ppm}(\mathbf{3 c})$ to $\delta=7.53 \mathrm{ppm}$ is detected $\left(3 \mathbf{c}+5\right.$ equiv. $\left.\mathrm{PhCO}_{2}{ }^{-}\right)$and is accompanied by a progressive shielding of all aromatic signals, be they part of the pyrene fragments of the receptor or the benzoate anion guest.

This study illustrates nicely the role of the amide protons in the recognition of the anion. Beyond this result, the evolution of the aromatic protons agrees with the contribution of $\pi-\pi$ interactions between aromatic counterparts in the host-guest complex, possibly intercalated as shown in Scheme 8 . This hypothesis is confirmed by the binding experiment with other anions. The ${ }^{1} \mathrm{H}$ NMR spectra of $\mathbf{3 c}$ recorded in the presence of two equivalents of various anions introduced as tetrabutylammonium salts is presented in Figure 3. It is clearly seen that the most important $\mathrm{N}-\mathrm{H}$ shift occurs with the benzoate anion, irrespectively of the basic strength within the anion series. An interesting additional result comes from the comparison between the ${ }^{1} \mathrm{H}$ NMR spectra of $\mathbf{3 c}$ with each of the two carboxylate

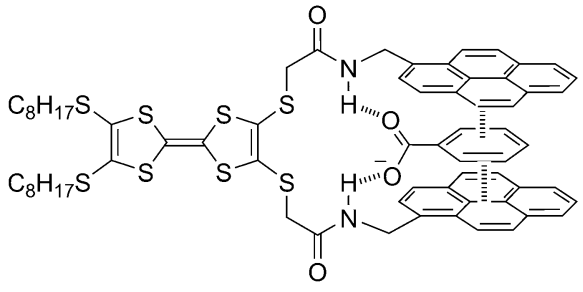

Scheme 8. Structural complementarity between $\mathbf{3 c}$ and a benzoate anion.

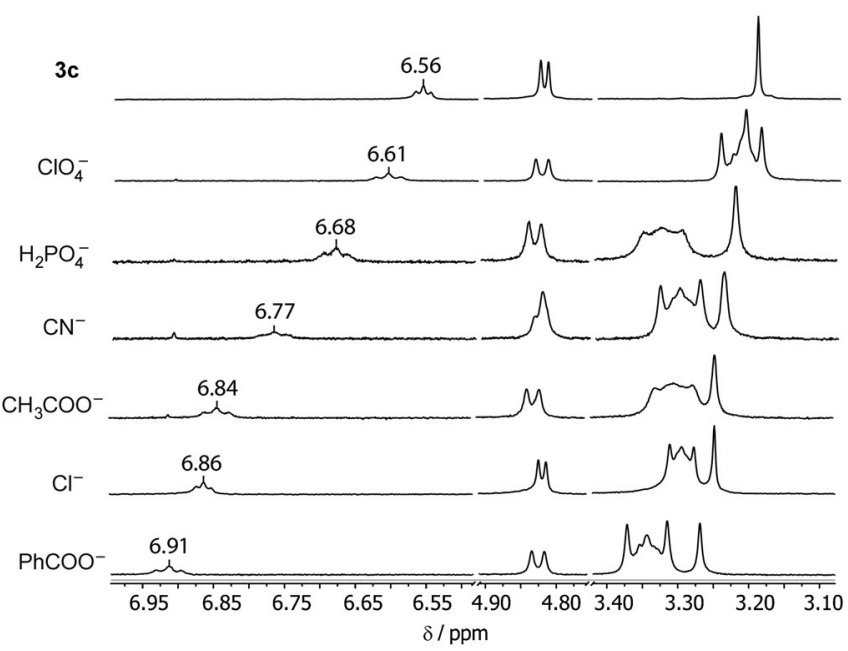

Figure $3 .{ }^{1} \mathrm{H}$ NMR study of receptor $3 \mathbf{c}(c=5.4 \mathrm{~mm})$ in the presence of two equivalents of various anions $\left(\mathrm{CDCl}_{3}\right.$, counterion $\left.=n \mathrm{Bu}_{4} \mathrm{~N}^{+}\right)$

anions, acetate, and benzoate. Though these carboxylate anions have similar $\mathrm{p} K_{\mathrm{a}}$ values, a significantly higher $\mathrm{NH}$ chemical shift occurs for $\mathbf{3 c}$ with the benzoate anion. This result accounts for the better affinity of $\mathbf{3 c}$ for benzoate over acetate anions, which is assigned to additional $\pi-\pi$ interactions occurring in the case of the former anion during the host-guest recognition process.

In addition to anion recognition and as a complementary entry to multifunctional gels, another potential interest in compound $\mathbf{3 c}$ lies in its luminescent properties, as this compound contains two photoactive pyrene units. The resulting donor-acceptor (D-A) dyad should, in principle, give rise to a quenching of the fluorescence supported by photoinduced electron or energy transfer from the $\pi$-donating TTF moiety (D) to the fluorescent accepting pyrene units (A). ${ }^{[1,22]}$ At this stage, an important issue of this system lies in the possibility to modulate the donating ability of the TTF unit by oxidation to the cation-radical or dication states, leading, therefore, to the restoration (at least partial) of the fluorescence of A. Such a concept has been recently successively developed with the preparation of several TTF-based fluorescence switches. ${ }^{[8 \mathrm{a}, 11 \mathrm{~b}, 23]}$ When such compounds contain an additional guest-binding subunit, these assemblies have also been applied to the construction of logic gates. ${ }^{[24]}$ Considering the structure of compound $\mathbf{3 c}$, which associates pyrene and TTF units as fluorescent and 
redox probes and also an anion binding site made up of secondary amide functions, we were interested in studying the extension of these concepts in the case of organogelator $\mathbf{3 c}$.

The absorption and emission spectra of $\mathbf{3} \mathbf{c}$ were recorded in dichloromethane (Figure 4). The former approximately corresponds to the sum of the spectra of chloroacetamide intermediate $\mathbf{2}$ and tetrakis(octylsulfanyl)-TTF used as a reference compound. Comparison of the emission spectra of

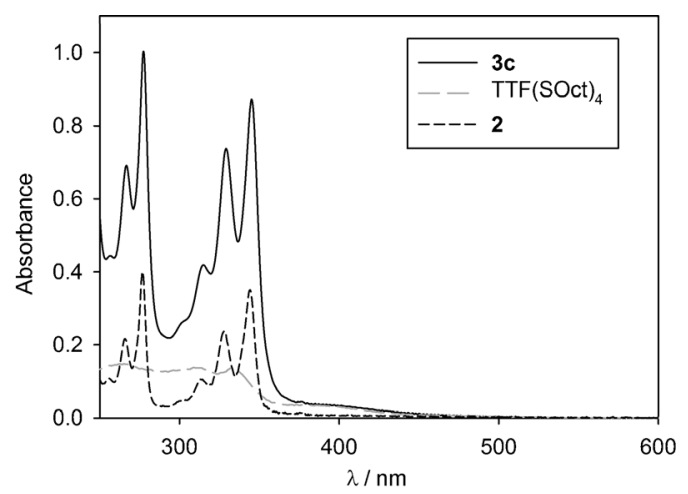

Figure 4. UV/vis absorption spectra of compounds $\mathbf{3 c}$, TTF(SOct $)_{4}$, and $2\left(\mathrm{CH}_{2} \mathrm{Cl}_{2}, c=1 \times 10^{-5} \mathrm{M}\right)$.

compounds $\mathbf{3 c}$ and $\mathbf{2}$ clearly demonstrates the expected fluorescence extinction in compound $\mathbf{3 c}$ (Figure 5). Contrariwise, the emission of derivative 7 appears very intense and is of the excimer type, which strongly suggests by analogy that compound $3 \mathbf{c}$ would have an excimer type emission if TTF was not quenching its luminescence.

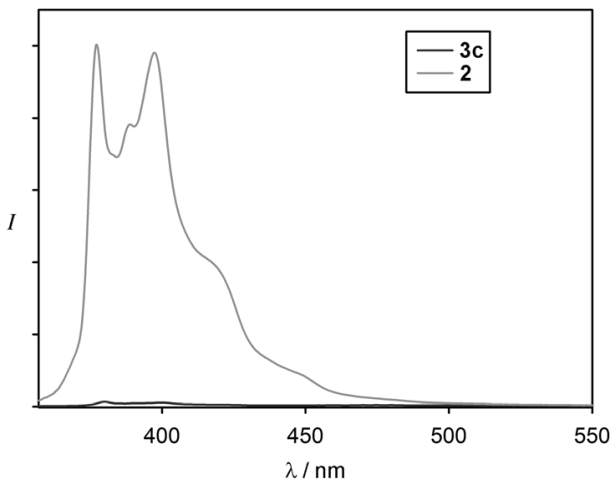

Figure 5. Emission spectra of compounds $\mathbf{3 c}$ and $\mathbf{2}\left(\mathrm{CH}_{2} \mathrm{Cl}_{2}, c=1 \times\right.$ $\left.10^{-5} \mathrm{~mol} \mathrm{~L}^{-1}, \lambda_{\mathrm{exc}}=347 \mathrm{~nm}\right)$.

Nevertheless, a residual fluorescence of the pyrene monomer type can be observed from this spectrum, which is therefore attributed to the presence of remaining pyrene besides compound 3c. Despite several successive purification steps (silica gel chromatography and recrystallization), this residual emission, though very low, is still observed. One explanation we suggest lies in the photochemical degradation of compound $\mathbf{3 c}$. This is confirmed by monitoring

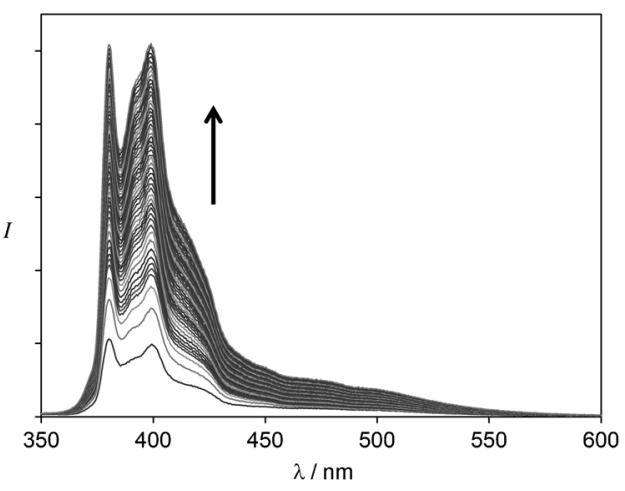

Figure 6. Evolution of the fluorescence emission spectra of $\mathbf{3 c}$ upon irradiation $\left(\mathrm{CH}_{2} \mathrm{Cl}_{2}, c=1 \times 10^{-5} \mathrm{~mol} \mathrm{~L}^{-1}, \lambda_{\mathrm{exc}}=347 \mathrm{~nm}\right)$.

the fluorescence emission of $\mathbf{3 c}$ with time (Figure 6), where a progressive increase of the monomer emission is clearly observed, to finally provide a comparable fluorescence spectrum to that of a solution of 1-hydroxymethylpyrene at the same concentration. The progressive restoring of pyrene emission is therefore assigned to the cleavage of the covalent link between TTF and pyrene subunits, leading to an increased concentration of free pyrene in the solution. The photochemical cleavage of $\mathrm{C}-\mathrm{O}$ bonds is established in the case of benzylic systems. ${ }^{[25]} \mathrm{By}$ analogy, we suggest that in the case of $3 \mathbf{c}$, cleavage of the $\mathrm{N}-\mathrm{CH}_{2}$ bond occurs at the benzylic position, leading to two stabilized radical species R-CONH • and $\mathrm{PyrCH}_{2}$. Such photodegradation is clearly inappropriate for exploring the fluorescent properties of $\mathbf{3 c}$ in solution or as a gel further, and we are currently working on the development of structurally analogous compounds based on the same building blocks (TTF, secondary amide, and pyrene) but devoid of any benzylic junctions.

\section{Conclusions}

A family of multifunctional organogelators that associate one redox-active TTF unit and one or two fluorescent pyrene platforms has been designed. These systems are built according a modular approach, which has allowed us to address the respective contribution of each parts of the molecule and, thus, to get a deeper insight into the gelation process. Two striking issues have to be considered from this systematic study. Firstly, contrariwise to the generally encountered situation, the presence of long alkyl chains is not required to get a gel from this class of compounds; compound 3a, bearing methyl groups, is able to gel 1,2-dichlorobenzene. Secondly, the presence of two secondary amide functions appears critical for getting a gel. In addition, the multifunctional character of $\mathbf{3 c}$ was explored by cyclic voltammetry, which shows a fully reversible oxidation sequence associated with the TTF subunit, ${ }^{1} \mathrm{H}$ NMR titration of anions, where it was shown that $\mathbf{3 c}$ has a good affinity for benzoate, and fluorescence spectroscopy. In the last 
case, we demonstrated that photochemical degradation of the compound occurs. Other systems based on the same building blocks (TTF, pyrene, secondary amide) but designed to avoid such degradation are being studied.

\section{Experimental Section}

All reagents were of commercial reagent grade and were used without further purification unless otherwise noted. Compounds $\mathbf{1 a}-\mathbf{c},{ }^{[7,12]} \mathbf{2}^{[13]}$ $\mathbf{3} \mathbf{c},{ }^{[7]} \mathbf{5}^{[14]} \mathbf{9}^{[16]} \mathbf{1 3},{ }^{[17 \mathrm{a}]}$ and $\mathbf{1 4}^{[17 \mathrm{a}]}$ were obtained according to the literature. All solutions were degassed prior to the experiments when thiolate functions were involved in the chemical transformation. Silica gel chromatography was performed with Sigma-Aldrich Chemistry $\mathrm{SiO}_{2}$ (pore size $60 \AA$ A , 40-63 $\mu \mathrm{m}$ technical grades). NMR spectra were recorded at room temperature (unless otherwise stated) on a NMR Bruker Avance III 300 spectrometer or Bruker Avance DRX 500. As TTF derivatives are sometimes sensitive to acidity, triethylamine was added when necessary to the NMR samples. MALDI-TOF MS spectra were recorded on a MALDI-TOF Bruker Bifle III instrument using a positive-ion mode. ESI-MS spectra were recorded on a Bruker MicrO-Tof-Q2 spectrometer. Cyclic voltammetry experiments were carried out on EG\&G PAR $273 \mathrm{~A}$ potentiostat using $n \mathrm{Bu}_{4} \mathrm{NPF}_{6}$ in $\mathrm{CH}_{2} \mathrm{Cl}_{2}(0.1 \mathrm{M})$. The electrochemical cell was equipped with a working electrode $(\mathrm{Pt}, \emptyset=2 \mathrm{~mm})$, a counter-electrode (Pt wire), and a silver electrode as a pseudoreference. Ferrocene was used to calibrate the voltammograms. UV/visible absorption spectra were recorded on a PerkinElmer Lamda19 spectrometer and fluorescence spectra were recorded on a Photon Technology International QuantaMaster 4.

\section{Compound 3 a}

A solution of cesium hydroxide monohydrate $(88 \mathrm{mg}, 0.53 \mathrm{mmol}$, 2.1 equiv.) dissolved in methanol $(7 \mathrm{~mL})$ was added to a solution of 2,3bis-(2-cyanoethylsulfanyl)-6,7-bis(methylsulfanyl)-tetrathiafulvalene (1aa, $117 \mathrm{mg}, 0.25 \mathrm{mmol})$ dissolved in $N, N$-dimethylformamide $(20 \mathrm{~mL})$. The mixture was stirred for $30 \mathrm{~min}$ and compound 2 (154 mg, $0.5 \mathrm{mmol}$, 2 equiv.) was added. After $12 \mathrm{~h}$ stirring at room temperature, the precipitate was isolated by filtration and successively rinsed with dichloromethane, acetone, and methanol (each $50 \mathrm{~mL}$ ). In this manner, the desired compound was isolated as an orange solid in $56 \%$ yield $(126 \mathrm{mg})$. m.p. $>$ $250{ }^{\circ} \mathrm{C} ;{ }^{1} \mathrm{H}$ NMR $\left(500 \mathrm{MHz}, 60^{\circ} \mathrm{C},\left[\mathrm{D}_{6}\right] \mathrm{DMSO}\right): \delta=8.61(\mathrm{t}, J=5.0 \mathrm{~Hz}$, $2 \mathrm{H}), 8.30-7.97(\mathrm{~m}, 18 \mathrm{H}), 4.98(\mathrm{~d}, J=5.0 \mathrm{~Hz}, 4 \mathrm{H}), 3.66(\mathrm{~s}, 4 \mathrm{H}), 2.34 \mathrm{ppm}$ $(\mathrm{s}, 6 \mathrm{H}),{ }^{13} \mathrm{C}$ NMR $\left(500 \mathrm{MHz}, 60^{\circ} \mathrm{C},\left[\mathrm{D}_{6}\right] \mathrm{DMSO}\right): \delta=166.6,131.8,130.5$, $130.0,129.9,127.9,127.3,127.3,127.0,126.8,126.3,126.2,125.9,124.9$, 124.8, 124.4, 123.8, 123.7, 122.8, 110.0, 108.6, 40.7, 39.4, 38.4, 18.1 ppm; HRMS (ESI): $m / z$ : calcd for $\mathrm{C}_{46} \mathrm{H}_{34} \mathrm{~N}_{2} \mathrm{O}_{2} \mathrm{~S}_{8}: 902.03859[M+\mathrm{H}]^{+}$; found 902.03778 .

\section{Compound $\mathbf{3 b}$}

A solution of cesium hydroxide monohydrate $(85 \mathrm{mg}, 0.51 \mathrm{mmol}$, 2.1 equiv.) dissolved in methanol $(3 \mathrm{~mL})$ was added to a solution of 2,3bis-(2-cyanoethylsulfanyl)-6,7-bis(pentylsulfanyl)tetrathiafulvalene (1) $140 \mathrm{mg}, 0.25 \mathrm{mmol})$ dissolved in $N, N$-dimethylformamide $(15 \mathrm{~mL})$. The mixture was stirred for $30 \mathrm{~min}$ and compound $2(149 \mathrm{mg}, 0.48 \mathrm{mmol}$, 2 equiv.) was added. After $12 \mathrm{~h}$ stirring at room temperature, the solvent was evaporated under vacuum. Compound $\mathbf{3 b}$ was isolated by silica gel chromatography (eluent: toluene/methanol $=996: 4$ ) and recrystallization from a dichloromethane/methanol mixture, which afforded the desired derivative in $60 \%$ yield $(147 \mathrm{mg}) . \mathrm{m} . \mathrm{p} .>180^{\circ} \mathrm{C}$ (degradation); ${ }^{1} \mathrm{H}$ NMR $\left(300 \mathrm{MHz},\left[\mathrm{D}_{6}\right] \mathrm{DMSO}\right): \delta=8.79(\mathrm{t}, J=5.5 \mathrm{~Hz}, 2 \mathrm{H}) ; 8.25(\mathrm{~d}$, $J=7.7 \mathrm{~Hz}, 2 \mathrm{H}) ; 8.23(\mathrm{~d}, J=7.5 \mathrm{~Hz}, 2 \mathrm{H}) ; 8.22(\mathrm{~d}, J=9.2 \mathrm{~Hz}, 2 \mathrm{H}) ; 8.15$ $(\mathrm{d}, J=7.9 \mathrm{~Hz}, 2 \mathrm{H}) ; 8.12(\mathrm{~d}, J=9.2 \mathrm{~Hz}, 2 \mathrm{H}) ; 8.11(\mathrm{~d}, J=8.9 \mathrm{~Hz}, 2 \mathrm{H})$; $8.06(\mathrm{~d}, J=9.0 \mathrm{~Hz}, 2 \mathrm{H}) ; 7.95(\mathrm{~d}, J=7.9 \mathrm{~Hz}, 2 \mathrm{H}) ; 4.93(\mathrm{~d}, J=5.5 \mathrm{~Hz}$, $4 \mathrm{H}) ; 3.68(\mathrm{~s}, 4 \mathrm{H}) ; 2.71(\mathrm{t}, J=7.2 \mathrm{~Hz}, 4 \mathrm{H}) ; 1.41\left(\mathrm{tt}, J=J^{\prime}=7.4 \mathrm{~Hz}, 4 \mathrm{H}\right)$; $1.16\left(\mathrm{tt}, J=J^{\prime}=7.3 \mathrm{~Hz}, 4 \mathrm{H}\right) ; 1.09\left(\mathrm{tt}, J=J^{\prime}=7.3 \mathrm{~Hz}, 4 \mathrm{H}\right) ; 0.70 \mathrm{ppm}(\mathrm{t}$, $J=7.2 \mathrm{~Hz}, 6 \mathrm{H}) ;{ }^{13} \mathrm{C} \mathrm{NMR}\left(300 \mathrm{MHz},\left[\mathrm{D}_{6}\right] \mathrm{DMSO}\right): \delta=166.9 ; 132.0$; $130.7 ; 130.2 ; 130.1 ; 128.0 ; 127.6 ; 127.5 ; 127.2 ; 127.0 ; 127.0 ; 126.4 ; 126.2$; $125.2 ; 125.1 ; 124.6 ; 124.0 ; 123.8 ; 123.0 ; 110.0 ; 108.9 ; 40.9 ; 38.5 ; 35.3$;
29.8; 28.8; 21.5; 13.7 ppm; HRMS (ESI): $m / z$ : calcd for $\mathrm{C}_{54} \mathrm{H}_{50} \mathrm{~N}_{2} \mathrm{O}_{2} \mathrm{~S}_{8}$ : 1014.16379 $[M+\mathrm{H}]^{+}$; found: 1014.16219 .

\section{2-(2-Cyanoethylsulfanyl)-3-(methylsulfanyl)-6,7- bis(octylsulfanyl)tetrathiafulvalene}

A solution of cesium hydroxide monohydrate $(133 \mathrm{mg}, 0.79 \mathrm{mmol}$, 1.05 equiv.) dissolved in methanol $(5 \mathrm{~mL})$ was added to a solution of 2,3bis(2-cyanoethylsulfanyl)-6,7-bis(octylsulfanyl)tetrathiafulvalene (1c, $500 \mathrm{mg}, 0.75 \mathrm{mmol})$ dissolved in $N, N$-dimethylformamide $(20 \mathrm{~mL})$. The mixture was stirred for $30 \mathrm{~min}$ and iodomethane $(0.4 \mathrm{~mL}, 7.5 \mathrm{mmol}$, 10 equiv.) was added. After $12 \mathrm{~h}$ stirring at room temperature, the solvent was evaporated under vacuum. The desired compound was isolated by silica gel chromatography (eluent: dichloromethane/petroleum ether $=3: 1)$ in $80 \%$ yield $(373 \mathrm{mg})$. m.p. $97^{\circ} \mathrm{C}$; ${ }^{1} \mathrm{H}$ NMR $(300 \mathrm{MHz}$, $\left.\mathrm{CDCl}_{3}\right): \delta=3.02(\mathrm{t}, J=7.3 \mathrm{~Hz}, 2 \mathrm{H}) ; 2.81(\mathrm{t}, J=7.4 \mathrm{~Hz}, 4 \mathrm{H}) ; 2.71(\mathrm{t}, J=$ $7.3 \mathrm{~Hz}, 2 \mathrm{H}) ; 2.47(\mathrm{~s}, 3 \mathrm{H}) ; 1.63\left(\mathrm{tt}, J=J^{\prime}=7.4 \mathrm{~Hz}, 4 \mathrm{H}\right) ; 1.40\left(\mathrm{tt}, J=J^{\prime}=\right.$ $7.2 \mathrm{~Hz}, 4 \mathrm{H}) ; 1.28(\mathrm{~m}, 16 \mathrm{H}) ; 0.88 \mathrm{ppm}(\mathrm{t}, J=6.9 \mathrm{~Hz}, 6 \mathrm{H}) ;{ }^{13} \mathrm{C}$ NMR $\left(300 \mathrm{MHz}, \mathrm{CDCl}_{3}\right): \delta=135.1 ; 127.9 ; 127.7 ; 119.9 ; 117.5 ; 112.8 ; 108.1$; $36.3 ; 31.8 ; 31.2 ; 29.7 ; 29.2 ; 29.1 ; 28.5 ; 22.6 ; 19.1 ; 18.7 ; 14.1$ ppm; HRMS (ESI): $m / z$ : calcd for $\mathrm{C}_{26} \mathrm{H}_{41} \mathrm{NS}_{8}: 623.1005[M+\mathrm{H}]^{+}$; found: 623.0993 .

\section{Compound $4 \mathrm{c}$}

A solution of cesium hydroxide monohydrate $(105 \mathrm{mg}, 0.62 \mathrm{mmol}$, 1.2 equiv.) in methanol $(5 \mathrm{~mL})$ was added to a solution of 2-(2-cyanoethylsulfanyl)-3-(methylsulfanyl)-6,7-bis(octylsulfanyl)tetrathiafulvalene (323 mg, $0.52 \mathrm{mmol})$ dissolved in $N, N$-dimethylformamide $(30 \mathrm{~mL})$. The mixture was stirred for $30 \mathrm{~min}$ and 2 -chloro- $N$-(1-pyrenylmethyl)acetamide $(\mathbf{2}, 160 \mathrm{mg}, 0.52 \mathrm{mmol}, 1$ equiv.) was added. After $12 \mathrm{~h}$ stirring at room temperature, the solvent was evaporated under vacuum. Compound $4 \mathbf{c}$ was isolated by silica gel chromatography (eluent: dichloromethane) in $27 \%$ yield (117 mg). m.p. $158^{\circ} \mathrm{C}$; ${ }^{1} \mathrm{H} \mathrm{NMR}(300 \mathrm{MHz}$, [D $\mathrm{D}_{6}$ DMSO): $\delta=8.22(\mathrm{~m}, 3 \mathrm{H}) ; 8.15(\mathrm{~m}, 2 \mathrm{H}) ; 8.08(\mathrm{~d}, J=8.9 \mathrm{~Hz}, 1 \mathrm{H})$; $8.05(\mathrm{~d}, J=8.9 \mathrm{~Hz}, 1 \mathrm{H}) ; 8.02\left(\mathrm{dd}, J=J^{\prime}=7.6 \mathrm{~Hz}, 1 \mathrm{H}\right) ; 7.95(\mathrm{~d}, J=$ $7.8 \mathrm{~Hz}, 1 \mathrm{H}) ; 7.11(\mathrm{t}, J=5.2 \mathrm{~Hz}, 1 \mathrm{H}) ; 5.15(\mathrm{~d}, J=5.4 \mathrm{~Hz}, 2 \mathrm{H}) ; 3.58(\mathrm{~s}$, $2 \mathrm{H}) ; 2.81(\mathrm{t}, J=7.4 \mathrm{~Hz}, 2 \mathrm{H}) ; 2.76(\mathrm{t}, J=7.4 \mathrm{~Hz}, 2 \mathrm{H}) ; 1.86(\mathrm{~s}, 3 \mathrm{H}) ; 1.61$ $\left(\mathrm{tt}, J=J^{\prime}=7.3 \mathrm{~Hz}, 2 \mathrm{H}\right) ; 1.57\left(\mathrm{tt}, J=J^{\prime}=7.3 \mathrm{~Hz}, 2 \mathrm{H}\right) ; 1.36(\mathrm{~m}, 4 \mathrm{H}) ; 1.24$ $(\mathrm{m}, 16 \mathrm{H}) ; 0.86 \mathrm{ppm}(\mathrm{m}, 6 \mathrm{H}) ;{ }^{13} \mathrm{C}$ NMR $\left(300 \mathrm{MHz},\left[\mathrm{D}_{6}\right] \mathrm{DMSO}\right): \delta=$ $166.6 ; 133.1 ; 131.2 ; 131.1 ; 129.4 ; 128.7 ; 128.4 ; 128.0 ; 127.9 ; 127.7 ; 127.5$; $127.4 ; 126.5 ; 125.9 ; 125.8 ; 125.3 ; 125.2 ; 125.0 ; 123.1 ; 121.8 ; 112.9 ; 108.5$; $42.7 ; 39.4 ; 36.7 ; 32.2 ; 30.1 ; 29.6 ; 29.5 ; 28.9 ; 23.0 ; 18.9 ; 14.3$ ppm; HRMS (ESI): $m / z$ : calcd for $\mathrm{C}_{42} \mathrm{H}_{51} \mathrm{NOS}_{8}: 841.1736[M+\mathrm{H}]^{+}$; found: 841.1736.

\section{Compound 6}

A mixture of [ $\left.\left(\mathrm{Et}_{4} \mathrm{~N}_{2}\right) \mathrm{Zn}(\mathrm{dmit})_{2}\right](359 \mathrm{mg}, 0.5 \mathrm{mmol}$ : dmit =1,3-dithiole2-thione-4,5-dithiolate) and compound 2 (616 mg, $2 \mathrm{mmol}, 4$ equiv.) was heated to reflux in acetonitrile $(150 \mathrm{~mL})$ for $24 \mathrm{~h}$. The yellow precipitate was isolated by filtration and successively rinsed with acetone $(50 \mathrm{~mL})$, water $(50 \mathrm{~mL})$, methanol $(50 \mathrm{~mL})$, and dichloromethane $(50 \mathrm{~mL})$. The desired compound was finally isolated by recrystallization from a dimethyl sulfoxide/methanol mixture in $65 \%$ yield $(480 \mathrm{mg})$. m.p. $>250^{\circ} \mathrm{C}$; ${ }^{1} \mathrm{H}$ NMR (300 MHz, [D $]$ DMSO): $\delta=8.88(\mathrm{t}, J=5.4 \mathrm{~Hz}, 2 \mathrm{H}) ; 8.35-7.95$ $(\mathrm{m}, 18 \mathrm{H}) ; 4.99(\mathrm{~d}, J=5.4 \mathrm{~Hz}, 4 \mathrm{H}) ; 3.77 \mathrm{ppm} \quad(\mathrm{s}, 4 \mathrm{H}) ;{ }^{13} \mathrm{C} \mathrm{NMR}$ (300 MHz, [D 6 DMSO): $\delta=211.5 ; 167.2 ; 137.1 ; 132.5 ; 131.3 ; 130.9$; $130.8 ; 128.7 ; 128.2 ; 127.8 ; 127.6 ; 127.4 ; 126.7 ; 125.8 ; 125.7 ; 125.2 ; 124.5$; 124.4; 123.6; 41.5; $39.3 \mathrm{ppm}$; HRMS (ESI): $\mathrm{m} / \mathrm{z}$ : calcd for $\mathrm{C}_{41} \mathrm{H}_{28} \mathrm{~N}_{2} \mathrm{O}_{2} \mathrm{~S}_{5} \mathrm{Na}: 763.06465[M+\mathrm{Na}]^{+}$; found: 763.06488 .

\section{Compound 7}

Compound 6 (59 mg, $0.08 \mathrm{mmol}$ ) was dissolved in dimethyl sulfoxide $(30 \mathrm{~mL})$ before addition of acetic acid $(5 \mathrm{~mL})$ and mercury acetate ( $66 \mathrm{mg}, 0.21 \mathrm{mmol}, 2.6$ equiv.) The reaction was stirred under an inert atmosphere overnight and filtered through hyflo super cel. A large amount of water was added and the desired compound precipitated from the solution, which was isolated by filtration. The solid was rinsed with water $(50 \mathrm{~mL})$, methanol $(30 \mathrm{~mL})$, and diethyl ether $(20 \mathrm{~mL})$, affording the pure compound 7 in $66 \%$ yield $(38 \mathrm{mg})$. m.p. $>250{ }^{\circ} \mathrm{C}$; ${ }^{1} \mathrm{H}$ NMR (300 MHz, [D $]$ DMSO): $\delta=8.84(\mathrm{t}, J=5.2 \mathrm{~Hz}, 2 \mathrm{H}) ; 8.31-7.98$ $(\mathrm{m}, 18 \mathrm{H}) ; 4.99(\mathrm{~d}, J=5.2 \mathrm{~Hz}, 4 \mathrm{H}) ; 3.72 \mathrm{ppm}(\mathrm{s}, 4 \mathrm{H}) ;{ }^{13} \mathrm{C} \mathrm{NMR}$ 
(300 MHz, $\left.\left[\mathrm{D}_{6}\right] \mathrm{DMSO}\right): \delta=189.3 ; 166.6 ; 131.9 ; 130.6 ; 130.1 ; 128.0$; $127.5 ; 127.3 ; 127.2 ; 127.1 ; 127.0 ; 126.7 ; 126.1 ; 125.1 ; 125.0 ; 124.5 ; 123.9$; 123.7; 123.0; 40.9; $38.7 \mathrm{ppm}$; HRMS (ESI): $\mathrm{m} / \mathrm{z}$ : calcd for $\mathrm{C}_{41} \mathrm{H}_{28} \mathrm{~N}_{2} \mathrm{O}_{3} \mathrm{~S}_{4} \mathrm{Na}: 747.08805[M+\mathrm{Na}]^{+}$; found: 747.08795 .

\section{Compound 8}

A mixture of catechol (55 mg, $0.5 \mathrm{mmol})$, compound 2 (308 mg, $1 \mathrm{mmol}$, 2 equiv.), potassium carbonate (173 $\mathrm{mg}, 1.25 \mathrm{mmol}, 2.5$ equiv.), and 18crown-6 (13 mg, $0.05 \mathrm{mmol}, 0.1$ equiv.) in acetonitrile $(50 \mathrm{~mL})$ was heated to reflux overnight. After cooling, the acetonitrile was evaporated in vacuo. Ethyl acetate $(100 \mathrm{~mL})$ and water $(100 \mathrm{~mL})$ were added. After extraction, the organic phase was washed with water $(2 \times 100 \mathrm{~mL})$ and subsequently dried over magnesium sulfate. The solvent was evaporated and $\mathbf{8}(31 \mathrm{mg})$ was isolated in $9 \%$ yield. m.p. $160^{\circ} \mathrm{C}$ (degradation); ${ }^{1} \mathrm{H}$ NMR $\left(300 \mathrm{MHz}, \mathrm{CDCl}_{3}\right): \delta=8.13(\mathrm{~m}, 4 \mathrm{H}) ; 8.01-7.91(\mathrm{~m}, 12 \mathrm{H}) ; 7.63$ $(\mathrm{d}, J=8.0 \mathrm{~Hz}, 2 \mathrm{H}) ; 6.90(\mathrm{t}, J=6.0 \mathrm{~Hz}, 2 \mathrm{H}) ; 6.78\left(\mathrm{dd}, J=6.0 \mathrm{~Hz}, J^{\prime}=\right.$ $3.5 \mathrm{~Hz}, 2 \mathrm{H}) ; 6.66\left(\mathrm{dd}, J=6 \mathrm{~Hz}, J^{\prime}=3.5 \mathrm{~Hz}, 2 \mathrm{H}\right) ; 4.86(\mathrm{~d}, J=6.0 \mathrm{~Hz}$, $4 \mathrm{H}) ; 4.33 \mathrm{ppm}(\mathrm{s}, 4 \mathrm{H}) ;{ }^{13} \mathrm{C}$ NMR could not be recorded because of the lack of solubility; HRMS (ESI): $m / z$ : calcd for $\mathrm{C}_{44} \mathrm{H}_{32} \mathrm{~N}_{2} \mathrm{O}_{4} \mathrm{Na}$ : 675.2260 $[M+\mathrm{Na}]^{+}$; found: 675.2256 .

\section{Compound $10 \mathrm{c}$}

Compound 16 (150 mg, $0.22 \mathrm{mmol})$ and triethylamine $(65 \mu \mathrm{L}-47 \mathrm{mg}$, $0.47 \mathrm{mmol}, 2.1$ equiv.) were added to anhydrous dichloromethane $(40 \mathrm{~mL})$. Afterwards, 4- $N, N$-dimethylaminopyridine $(164 \mathrm{mg}, 1.34 \mathrm{mmol}$, 6 equiv.), 1-ethyl-3-(3-dimethylamino-propyl)carbodiimide hydrochloride (256 mg, $1.34 \mathrm{mmol}, 6$ equiv.), and 1-hydroxybenzotriazole (90 mg, $0.67 \mathrm{mmol}, 3$ equiv.) were successively added. After $15 \mathrm{~min}$ stirring, 1-hydroxymethylpyrene (104 mg, $0.44 \mathrm{mmol}, 2$ equiv.) was added. The mixture was stirred at room temperature under an inert atmosphere for $48 \mathrm{~h}$, then the solvent was evaporated in vacuo. Compound $10 \mathrm{c}$ was finally isolated by silica gel chromatography as a yellow paste (eluent: dichloromethane/petroleum ether $=8: 2)$ in $50 \%$ yield $(122 \mathrm{mg}) .{ }^{1} \mathrm{H} \mathrm{NMR}$ $\left(300 \mathrm{MHz}\right.$, acetone- $\left.\mathrm{D}_{6}\right): \delta=8.27-7.98(\mathrm{~m}, 18 \mathrm{H}) ; 5.82(\mathrm{~s}, 4 \mathrm{H}) ; 3.70(\mathrm{~s}$, $4 \mathrm{H}) ; 2.73(\mathrm{t}, J=7.2 \mathrm{~Hz}, 4 \mathrm{H}) ; 1.48\left(\mathrm{tt}, J=J^{\prime}=7.3 \mathrm{~Hz}, 4 \mathrm{H}\right) ; 1.29-1.14(\mathrm{~m}$, $20 \mathrm{H}) ; 0.82 \mathrm{ppm}(\mathrm{t}, J=6.9 \mathrm{~Hz}, 6 \mathrm{H}) ;{ }^{13} \mathrm{C} \mathrm{NMR}\left(300 \mathrm{MHz}\right.$, acetone-D ${ }_{6}$ ): $\delta=170.1 ; 133.6 ; 133.1 ; 132.6 ; 131.3 ; 130.6 ; 130.4 ; 130.0 ; 129.7 ; 129.6$; $129.5 ; 129.2 ; 128.0 ; 127.4 ; 126.5 ; 126.4 ; 126.2 ; 124.9 ; 112.4 ; 110.7 ; 67.3$ $56.0 ; 38.9 ; 37.6 ; 33.5 ; 31.4 ; 30.7 ; 30.0 ; 24.3 ; 15.3$ ppm; HRMS (MALDITOF): $m / z$ : calcd for $\mathrm{C}_{60} \mathrm{H}_{60} \mathrm{O}_{4} \mathrm{~S}_{8}: 1100.2257[M+\mathrm{H}]^{+}$; found: 1100.2253.

\section{Compound 11}

A mixture of $\left[\left(\mathrm{Et}_{4} \mathrm{~N}_{2}\right) \mathrm{Zn}(\mathrm{dmit})_{2}\right](89 \mathrm{mg}, 0.12 \mathrm{mmol})$ and compound 9 (148 mg, $0.48 \mathrm{mmol}, 4$ equiv.) was heated to reflux in acetonitrile $(30 \mathrm{~mL})$ for two hours. The solvent was evaporated in vacuo and the corresponding residue was dissolved in dichloromethane $(50 \mathrm{~mL})$. This organic phase was washed with water $(100 \mathrm{~mL})$ and dried over magnesium sulfate before evaporation of the solvent. The desired derivative was purified by silica gel chromatography (eluent: dichloromethane/acetone = $99: 1)$ in $79 \%$ yield $(147 \mathrm{mg})$. m.p. $134{ }^{\circ} \mathrm{C} ;{ }^{1} \mathrm{H}$ NMR $\left(300 \mathrm{MHz}, \mathrm{CDCl}_{3}\right)$ $\delta=8.12(\mathrm{~m}, 8 \mathrm{H}) ; 8.03(\mathrm{~d}, J=7.8 \mathrm{~Hz}, 2 \mathrm{H}) ; 7.98(\mathrm{~m}, 4 \mathrm{H}) ; 7.93(\mathrm{~m}, 4 \mathrm{H})$ $5.76(\mathrm{~s}, 4 \mathrm{H}) ; 3.44 \mathrm{ppm}(\mathrm{s}, 4 \mathrm{H}) ;{ }^{13} \mathrm{C} \mathrm{NMR}\left(300 \mathrm{MHz}, \mathrm{CDCl}_{3}\right): \delta=209.7$ $167.9 ; 136.3 ; 131.9 ; 131.0 ; 130.5 ; 129.6 ; 128.4 ; 128.1 ; 128.0 ; 127.5 ; 127.2$; $126.1 ; 125.6 ; 124.7 ; 124.5 ; 122.5 ; 66.2 ; 37.5 \mathrm{ppm}$; HRMS (ESI): $\mathrm{m} / z$ : calcd for $\mathrm{C}_{41} \mathrm{H}_{26} \mathrm{O}_{4} \mathrm{~S}_{5} \mathrm{Na}$ : $765.03268[M+\mathrm{Na}]^{+}$; found: 765.03249 .

\section{Compound 12}

Compound 11 (130 mg, $0.18 \mathrm{mmol})$ was dissolved in chloroform (15 mL) before addition of acetic acid $(5 \mathrm{~mL})$ and mercury acetate $(145 \mathrm{mg}$, $0.46 \mathrm{mmol}, 2.6$ equiv.). The reaction was stirred under inert atmosphere for four hours and filtered over hyflo super cel. The filtrate was washed with a saturated solution of sodium hydrogenocarbonate $(100 \mathrm{~mL})$ and water $(2 \times 100 \mathrm{~mL})$. The organic layer was dried over magnesium sulfate and concentrated in vacuo. The desired derivative was isolated by silica gel chromatography (eluent: dichloromethane) in $92 \%$ yield $(117 \mathrm{mg})$. m.p. $115^{\circ} \mathrm{C} ;{ }^{1} \mathrm{H} \mathrm{NMR}\left(300 \mathrm{MHz}, \mathrm{CDCl}_{3}\right): \delta=8.16-7.92(\mathrm{~m}, 18 \mathrm{H}) ; 5.77$ (s, 4H); 3.46 ppm (s, 4H); ${ }^{13} \mathrm{C} \mathrm{NMR}\left(300 \mathrm{MHz}, \mathrm{CDCl}_{3}\right): \delta=188.3 ; 168.1$;
$131.9 ; 131.0 ; 130.5 ; 129.5 ; 128.4 ; 128.1 ; 128.0 ; 127.9 ; 127.6 ; 127.2 ; 126.1$; $125.6 ; 125.5 ; 124.7 ; 124.5 ; 124.4 ; 122.6 ; 66.2 ; 37.7$ ppm.

\section{Compound 15}

An equimolar mixture of 4,5-bis(methoxycarbonylmethylsulfanyl)-1,3-dithiole-2-one $(\mathbf{1 4}, 326 \mathrm{mg}, 1 \mathrm{mmol})$ and 4,5-bis(octylsulfanyl)-1,3-dithiole2-thione (423 mg, $1 \mathrm{mmol}$ ) was dissolved in toluene $(15 \mathrm{~mL})$ and freshly distilled triethylphosphite $(5 \mathrm{~mL})$ was added. This mixture was heated to reflux overnight under an inert atmosphere. After cooling, the toluene was evaporated under vacuum. A large amount of petroleum ether (ca. $200 \mathrm{~mL}$ ) was added to precipitate an orange solid, which was isolated by filtration. This solid was purified by silica gel chromatography (eluent: dichloromethane/petroleum ether $=1: 1$ ) to obtain the desired compound in $34 \%$ yield $(237 \mathrm{mg})$. m.p. $55^{\circ} \mathrm{C}$; ${ }^{1} \mathrm{H} \mathrm{NMR}(300 \mathrm{MHz}$, $\left.\mathrm{CDCl}_{3}\right): \delta=3.77(\mathrm{~s}, 6 \mathrm{H}) ; 3.59(\mathrm{~s}, 4 \mathrm{H}) ; 2.80(\mathrm{t}, J=6.4 \mathrm{~Hz}, 4 \mathrm{H}) ; 1.62(\mathrm{tt}$, $\left.J=J^{\prime}=7.4 \mathrm{~Hz}, 4 \mathrm{H}\right) ; 1.40 \quad\left(\mathrm{tt}, \quad J=J^{\prime}=7.1 \mathrm{~Hz}, 4 \mathrm{H}\right) ; 1.28 \quad(\mathrm{~m}, 16 \mathrm{H})$; $0.88 \mathrm{ppm}(\mathrm{t}, J=7.0 \mathrm{~Hz}) ;{ }^{13} \mathrm{C} \mathrm{NMR}\left(300 \mathrm{MHz}, \mathrm{CDCl}_{3}\right): \delta=168.9 ; 128.9$; $127.8 ; 112.4 ; 108.3 ; 52.8 ; 37.4 ; 36.3 ; 31.8 ; 29.7 ; 29.1 ; 29.0 ; 28.5 ; 22.6$; $14.1 \mathrm{ppm}$; HRMS (ESI): $m / z$ : calcd for $\mathrm{C}_{28} \mathrm{H}_{44} \mathrm{O}_{4} \mathrm{~S}_{8}: 700.1005[M+\mathrm{H}]^{+}$; found: 700.1004 .

\section{Compound 16}

Compound 15 (222 mg, $0.33 \mathrm{mmol}$ ) and sodium hydroxide (262 mg, $6.6 \mathrm{mmol}, 20$ equiv.) were added to a mixture of tetrahydrofuran $(20 \mathrm{~mL})$, methanol $(10 \mathrm{~mL})$, and water $(5 \mathrm{~mL})$. The reaction was heated to reflux overnight under an inert atmosphere. After cooling, the tetrahydrofuran and methanol were evaporated under vacuum and water $(30 \mathrm{~mL})$ was added. The $\mathrm{pH}$ was adjusted to 2 by addition of a $1 \mathrm{~m}$ aqueous solution of hydrochloric acid. The mixture was stirred for $15 \mathrm{~min}$ and the orange precipitate was isolated by filtration, then rinsed with water $(200 \mathrm{~mL})$ and acetonitrile $(50 \mathrm{~mL})$. In this manner, the desired compound was isolated in quantitative yield $(215 \mathrm{mg})$. m.p. $128^{\circ} \mathrm{C}$; ${ }^{1} \mathrm{H}$ NMR $\left(300 \mathrm{MHz}, \mathrm{CDCl}_{3}\right): \delta=3.63(\mathrm{~s}, 4 \mathrm{H}) ; 2.79(\mathrm{t}, J=7.4 \mathrm{~Hz}, 4 \mathrm{H})$; $1.61\left(\mathrm{tt}, J=J^{\prime}=7.4 \mathrm{~Hz}, 4 \mathrm{H}\right) ; 1.39\left(\mathrm{tt}, J=J^{\prime}=6.9 \mathrm{~Hz}, 4 \mathrm{H}\right) ; 1.29(\mathrm{~m}, 16 \mathrm{H})$; $0.88 \mathrm{ppm}(\mathrm{t}, J=6.9 \mathrm{~Hz}, 6 \mathrm{H})$; HRMS (ESI): $m / z$ : calcd for $\mathrm{C}_{26} \mathrm{H}_{40} \mathrm{O}_{4} \mathrm{~S}_{8}$ : $672.06923[M+\mathrm{H}]^{+}$; found: 672.06860 .

\section{Acknowledgements}

D.C. thanks the Ministère de l'Enseignement et de la Recherche for a $\mathrm{PhD}$ grant. D.C. and M.S. thank the COST D31 Action (Organizing Non-Covalent Chemical Systems with Selected Functions). We are grateful to the Plateforme d'Ingénierie et d'Analyses Moléculaires (PIAM) and thank David B. Amabilino for fruitful discussions.

[1] a) P. Terech, R. G. Weiss, Chem. Rev. 1997, 97, 3133-3159; b) N. M. Sangeetha, U. Maitra, Chem. Soc. Rev. 2005, 34, 821-836; c) L. E. Buerkle, S. J. Rowan, Chem. Soc. Rev. 2012, 41, 6089-6102.

[2] a) J. B. Beck, S. J. Rowan, J. Am. Chem. Soc. 2003, 125, 1392213923 ; b) J. Liu, P. He, J. Yan, X. Fang, J. Peng, K. Liu, Y. Fang, Adv. Mater. 2008, 20, 2508-2511; c) E. Krieg, E. Shirman, H. Weissman, E. Shimoni, S. G. Wolf, I. Pinkas, B. Rybtchinski, J. Am. Chem. Soc. 2009, 131, 14365-14373; d) C. Wang, Q. Chen, F. Sun, D. Zhang, G. Zhang, Y. Huang, R. Zhao, D. Zhu, J. Am. Chem. Soc. 2010, 132, 3092-3096; e) Y. Jiang, F. Zeng, R. Gong, Z. Guo, C.-F. Chen, X. Wan, Soft Matter 2013, 9, 7538-7544.

[3] a) K. K. Kartha, S. S. Babu, S. Srinivasan, A. Ajayaghosh, J. Am. Chem. Soc. 2012, 134, 4834-4841; b) T. H. Kim, M. S. Choi, B.-H. Sohn, S.-Y. Park, W. S. Lyoo, T. S. Lee, Chem. Commun. 2008, 2364-2366.

[4] a) Z. Qi, P. Malo de Molina, W. Jiang, Q. Wang, K. Nowosinski, A. Schulz, M. Gradzielski, C. A. Schalley, Chem. Sci. 2012, 3, $2073-$ 2082 ; b) P. Xue, R. Lu, J. Jia, M. Takafuji, H. Ihara, Chem. Eur. J. 2012, 18, 3549-3558; c) L. Zang, H. Shang, D. Wei, S. Jiang, Sens. Actuators B 2013, 185, 389-397. 
[5] a) A. Dawn, T. Shiraki, S. Haraguchi, S.-i. Tamaru, S. Shinkai, Chem. Asian J. 2011, 6, 266-282; b) J. W. Steed, Chem. Commun. 2011, 47, 1379-1383.

[6] J. H. van Esch, Langmuir 2009, 25, 8392-8394.

[7] D. Canevet, A. Pérez Del Pino, D. B. Amabilino, M. Sallé, J. Mater. Chem. 2011, 21, 1428-1437.

[8] a) D. Canevet, M. Sallé, G. Zhang, D. Zhang, D. Zhu, Chem. Commun. 2009, 2245-2269; b) N. Martín, J.-L. Segura, Angew. Chem. 2001, 113, 1416-1455; Angew. Chem. Int. Ed. 2001, 40 1372-1409.

[9] D. Canevet, A. Pérez Del Pino, D. B. Amabilino, M. Sallé, Nanoscale 2011, 3, 2898-2902.

[10] a) S. O. Kang, R. A. Begum, K. Bowman-James, Angew. Chem. 2006, 118, 8048-8061; Angew. Chem. Int. Ed. 2006, 45, 7882-7894; b) P. A. Gale, Acc. Chem. Res. 2006, 39, 465-475.

[11] a) X. Xiao, W. Xu, D. Zhang, H. Xu, L. Liu, D. Zhu, New J. Chem. 2005, 29, 1291-1294; b) L. Liu, G. Zhang, W. Tan, D. Zhang, D. Zhu, Chem. Phys. Lett. 2008, 465, 230-233.

[12] K. B. Simonsen, N. Svenstrup, J. Lau, O. Simonsen, P. Mørk, G. J. Kristensen, J. Becher, Synthesis 1996, 3, 407-418.

[13] N. J. van der Veen, S. Flink, M. A. Deij, R. J. M. Egberink, F. C. J. M. van Veggel, D. N. Reinhoudt, J. Am. Chem. Soc. 2000, 122, 6112-6113.

[14] a) G. Steimecke, H. J. Sieler, R. Kirmse, E. Hoyer, Phosphorus, Sulfur, Silicon Relat. Elem. 1979, 7, 49; b) C. S. Wang, A. S. Batsanov, M. R. Bryce, J. A. K. Howard, Synthesis 1998, 1615-1618.

[15] P. Batail, Chem. Rev. 2004, 104, Special issue on Molecular Conductors.

[16] S. H. Lee, S. H. Kim, S. K. Kim, J. H. Jung, J. S. Kim, J. Org. Chem. 2005, 70, 9288-9295.

[17] a) G. C. Papavassiliou, V. C. Kakoussis, G. A. Mousdis, J. S. Zambounis, C. W. Mayer, Chem. Scr. 1989, 29, 71-73; b) B. T. Zhao, M. J. Blesa, F. Le Derf, D. Canevet, C. Benhaoua, M. Mazari, M Allain, M. Sallé, Tetrahedron 2007, 63, 10768-10777.

[18] a) K. Kawai, K. Miyamoto, S. Tojo, T. Majima, J. Am. Chem. Soc. 2003, 125, 912-915; b) K. Kawai, H. Yoshida, T. Takada, S. Tojo, T.
Majima, J. Phys. Chem. B 2004, 108, 13547-13550; c) K. Kawai, T. Kimura, H. Yoshida, A. Sugimoto, S. Tojo, M. Fujitsuka, T. Majima, Bull. Chem. Soc. Jpn. 2006, 79, 312-316.

[19] a) M. Hissler, A. Harriman, A. Khatyr, R. Ziessel, Chem. Eur. J. 1999, 5, 3366-3381; b) A. Knorr, J. Daub, Angew. Chem. 1995, 107, 2925-2927; Angew. Chem. Int. Ed. Engl. 1995, 34, 2664-2666; c) T. Gareis, O. Köthe, J. Daub, Eur. J. Org. Chem. 1998, 1549-1557.

[20] H. Lu, W. Xu, D. Zhang, C. Chen, D. Zhu, Org. Lett. 2005, 7, 4629-4632.

[21] M. Hardouin-Lerouge, P. Hudhomme, M. Sallé, Chem. Soc. Rev. 2011, 40, 30-43.

[22] G. Pagona, A. S. D. Sandanayaka, A. Maigné, J. Fan, G. C. Papavassiliou, I. D. Petsalakis, B. R. Steele, M. Yudasaka, S. Iijima, N. Tagmatarchis, O. Ito, Chem. Eur. J. 2007, 13, 7600-7607.

[23] a) Y. Zhang, L.-Z. Cai, C.-Y. Wang, G.-Q. Lai, Y.-J. Shen, New J. Chem. 2008, 32, 1968-1973; b) H. Fujiwara, Y. Sugishima, K. Tsujimoto, Tetrahedron Lett. 2008, 49, 7200-7203; c) Y. Zhang, Z. Xu, L. Cai, G. Lai, H. Qiu, Y. Shen, J. Photochem. Photobiol. A 2008, 200, 334-345; d) K. Nielsen, E. Levillain, V. M. Lynch, J. L. Sessler, J. O. Jeppesen, Chem. Eur. J. 2009, 15, 506-516; e) M. Å. Petersen, A. S. Andersson, K. Kilså, M. B. Nielsen, Eur. J. Org. Chem. 2009, 1855-1858; f) Y. Zhang, Z. Xu, H.-x. Qiu, G.-q. Lai, Y.-j. Shen, J. Photochem. Photobiol. A 2009, 204, 32-38; g) X.-C. Zhang, Y. Zhang, C.-Y. Wang, G.-Q. Lai, L. Zhang, Y.-J. Shen, Polym. Bull. 2009, 63, 815-827; h) C. Wang, W. Tang, H. Zhong, X. Zhang, Y. Shen, J. Heterocycl. Chem. 2009, 46, 881-885; i) C.-H. Xu, W. Sun, C. Zhang, C. Zhou, C. J. Fang, C. H. Yan, Chem. Eur. J. 2009, 15, $8717-8721$.

[24] a) G. Zhang, D. Zhang, Y. Zhou, D. Zhu, J. Org. Chem. 2006, 71, 3970-3972; b) D. C. Magri, New J. Chem. 2009, 33, 457-461; c) F. M. Winnik, Chem. Rev. 2002, 102, 587-614.

[25] N. Madhavan, M. S. Gin, Chem. Commun. 2004, 2728-2729.

Received: December 1, 2013

Revised: December 30, 2013 Published online: February 4, 2014 